\title{
Biotic factors and occurrence of Lutzomyia longipalpis in endemic area of visceral leishmaniasis, Mato Grosso do Sul, Brazil
}

\author{
Everton Falcão de Oliveira ${ }^{1 /+}$, Elaine Araújo e Silva ${ }^{2}$, Carlos Eurico dos Santos Fernandes ${ }^{3}$, \\ Antonio Conceição Paranhos Filho ${ }^{4}$, Roberto Macedo Gamarra ${ }^{4}$, Alisson André Ribeiro ${ }^{4}$, \\ Reginaldo Peçanha Brazil ${ }^{5}$, Alessandra Gutierrez de Oliveira ${ }^{1,3}$
}

\author{
${ }^{1}$ Programa de Pós-graduação em Doenças Infecciosas e Parasitárias, Faculdade de Medicina Dr Hélio Mandetta \\ ${ }^{3}$ Laboratório de Parasitologia, Centro de Ciências Biológicas e da Saúde ${ }^{4}$ Laboratório de Geoprocessamento para Aplicações Ambientais, \\ Centro de Ciências Exatas e Tecnológicas, Universidade Federal de Mato Grosso do Sul, Campo Grande, MS, Brasil \\ ${ }^{2}$ Centro de Controle de Zoonoses, Secretaria Municipal de Saúde de Campo Grande, Campo Grande, MS, Brasil \\ ${ }^{5}$ Departamento de Bioquímica e Biologia Molecular, Instituto Oswaldo Cruz-Fiocruz, Rio de Janeiro, RJ, Brasil
}

The relationships between environmental exposure to risk agents and health conditions have been studied with the aid of remote sensing imagery, a tool particularly useful in the study of vegetation cover. This study aims to evaluate the influence of environmental variables on the spatial distribution of the abundance of Lutzomyia longipalpis and the reported canine and human visceral leishmaniasis (VL) cases at an urban area of Campo Grande, state of Mato Grosso do Sul. The sandfly captures were performed in 13 residences that were selected by raffle considering four residences or collection station for buffer. These buffers were generated from the central house with about 50, 100 and $200 \mathrm{~m}$ from it in an endemic area of VL. The abundance of sandflies and human and canine cases were georreferenced using the GIS software PCI Geomatica. The normalized difference vegetation index (NDVI) and percentage of land covered by vegetation were the environmental variables extracted from a remote sensing IKONOS-2 image. The average NDVI was considered as the complexity of habitat and the standard deviation as the heterogeneity of habitat. One thousand three hundred sixty-seven specimens were collected during the catch. We found a significant positive linear correlation between the abundance of sandflies and the percentage of vegetation cover and average NDVI. However, there was no significant association between habitat heterogeneity and the abundance of these flies.

Key words: Lutzomyia longipalpis - geotechnologies - vegetation cover - spatial analysis - leishmaniasis

Sandflies (Diptera: Psychodidae) have medical importance due the fact that they are vectors of some parasites, especially Leishmania. In Brazil, visceral leishmaniasis $(\mathrm{VL})$ is characterized as a major public health problem and is emerging in different urban areas (Costa et al. 2007).

In Campo Grande, state of Mato Grosso do Sul (MS), the first record for autochthonous canine VL occurred in 1998 (Silva et al. 2000). The presence of Lutzomyia longipalpis, the main vector of VL in Americas, was first observed in the city in 2000 (Oliveira et al. 2000). The following entomological surveys showed year-round prevalence of Lu. longipalpis in urban areas, with higher density in the rainy season, confirming their preference for environments modified by human action (Oliveira et al. 2003, 2006).

According to the State Secretariat of Health of Mato Grosso do Sul, the first autochthonous human VL cases at Campo Grande were reported in 2001, characterizing the beginning of the epidemics of VL in the state capital. Currently, VL remains in geographical expansion affecting young and adults of any age at rural and urban areas. In

+ Corresponding author: evertonfalcaodeoliveira@yahoo.com.br Received 9 July 2011

Accepted 14 December 2011 the year 2010, 221 cases were registered in the state and, of these, 127 occurred in Campo Grande (SES/MS 2011).

In recent years, there has been a significant development of studies that seek to relate health to environment. The relationship between environmental exposure to risk agents and health conditions have been studied with the aid of geotechnologies, such as remote sensing, which provide important information for surveillance, monitoring and mapping the risk of several diseases (Barcellos \& Bastos 1996, Beck et al. 2000).

Some sensors have been used to map the distribution of vector-borne diseases and their vectors. In the Old World, Özbel et al. (2011) used Landsat ETM+ satellite images to study the spatial distribution of sandflies in Turkey. In Brazil, Antonialli et al. (2007) analyzed the spatially spread of VL over the years, showing the migration route of the disease from Corumbá, MS, to the city of Bauru, in the state of São Paulo.

The occurrence of sandflies is usually associated with the presence of forests, although they can also be found in open areas and in urban environments (Galati et al. 2003, 2006, Lainson \& Rangel 2005). At both regional and local scales, the models of spatial and temporal distributions of sandfly populations are influenced by temperature, humidity, light and altitude (Forattini 1973). Thus, in analyzing the vegetation, we analyze indirectly all these factors (Aparicio 2001).

Different vegetation indices can be used for the study and evaluation of vegetation. Among those have already 
described in the literature, there is the normalized difference vegetation index (NDVI) that is indicative of the amount of biomass in the region and has direct relationship with the plant biomass, allowing to characterize some aspects of vegetation biophysical (Aparicio 2001, Rosa 2003, Ponzoni \& Shimabukuro 2007). Another way to measure the amount of biomass present in a geographic area is caused by direct field measurement of the percentage of vegetation cover using a spherical densitometer that is very useful for obtaining accurate and reliable estimates of vegetation cover small areas at a lower cost (Stumpf 1993).

Landscape ecology studies the sets of habitats located in the same region, as well as the interactions between them. The spatial components of the landscape, the complexity and spatial heterogeneity directly influence the diversity and distribution of organisms affecting variables such as the presence and abundance of species and biotic interactions (Chust et al. 2004, Dajoz 2005, Hirao et al. 2008).

The precise characterization of the spatial structure of the biomass allows establishing the architecture of the ecosystem. The structural aspects that correspond to the vertical plane and those that reflect the spatial heterogeneity in the horizontal plane are considered separately (Sarmiento 1984). The complexity of habitat can be define as the density and development of the vertical strata of vegetation in a given unit area (Root 1973, Dajoz 2005) and the heterogeneity of habitat as the structure of vegetation in the horizontal plane (Sarmiento 1984, Dajoz 2005).

This study aims to evaluate the influence of environmental variables on the spatial distribution of the abundance of Lu. longipalpis and the reported canine and human VL cases at an urban area of Campo Grande, MS.

\section{MATERIALS AND METHODS}

Study area - The municipality of Campo Grande $\left(20^{\circ} 26^{\prime} 34^{\prime \prime} \mathrm{S} 54^{\circ} 38^{\prime} 47^{\prime \prime} \mathrm{W}, \mathrm{Gr}\right)$ has a total area of 8.118.4 $\mathrm{km}^{2}$ and is located in the central portion of the state, occupying $2.27 \%$ of its total area, and its altitude varies between $500-675 \mathrm{~m}$ (Fig. 1). The city is situated in the area belonging to the neotropical phytogeographic areas of cerrado region. The climate of Campo Grande, according to the classification of Köppen, is of the type wet tropical savanna, characterized by irregular distribution of rainfall annually, with occurrence of a well defined dry season during the coldest months of year and a rainy season during the summer months (Rohli \& Veja 2008, PMCG/ PLANURB 2010). According to estimates by the Brazilian Institute of Geography and Statistics (IBGE 2010) the urban population in 2010 was 766,461 inhabitants.

Within the city of Campo Grande, located in the western portion of the city, the neighbourhood of Santo Antonio was selected for study. This choice was based on two criteria: (i) reports of human and canine cases in the years prior to the start of research and (ii) high population density of sandflies, according to the information passed on by the Centre of Zoonosis Control (CCZ) of the Municipal Health Secretariat, based on entomological survey carried out between January 2008-July 2009. According to the stratification of human VL cases by neighbour- hood, provided by the State Department of Health, from January 2003-December 2008 the district was classified as an area of moderate transmission of the disease.

Data collection - The sandfly captures were performed in the peridomicile (or collection station) of 13 residences between November 2009-November 2010. The selection has done by raffle considering four residences or collection station for buffer. These buffers were generated from the central house (residence 1) with about 50,100 and $200 \mathrm{~m}$ from it (Fig. 1). This method of selection was choosing because we have already worked in this area in other study. During this period weekly collections were made every other month, totalling 24 catches. Three CDC light traps were installed in the peridomicile with approximately $5 \mathrm{~m}$ distance from each other at either collection station, totalling 39 units. Traps were set at 05:00 pm and removed at 07:00 am the next day. The abundance obtained during the collection was organized by convenience into five categories: up to $20,21-50$, from 51-100, 101-500 and more than 500 specimens.

We used data from reporting cases of human and canine LV residents in the neighbourhood of San Antonio from January 2009-December 2010. The reports of human VL cases were taken from the official database of the Information System for Notifiable Diseases in MS and notifications of cases of canine VL were provided by the CCZ from Campo Grande. We considered previous report canine cases (January 2009-November 2009) just to show that the disease was present in the area.

We used an IKONOS-2 image with spatial resolution of $4 \mathrm{~m}$ for the multispectral bands and $1 \mathrm{~m}$ for panchromatic band of 5 March 2006 of the urban area of Campo Grande. The projection used was Universal Transverse Mercator, the Southern Hemisphere, zone 21 and datum WGS84. The abundance of sandflies and human and canine cases were spatialized using the GIS software PCI Geomatica vs. 9.1 for Windows (PCI Geomatics 2003, Ontário, Canadá). The environmental variables used in this study were the NDVI and the percentage of vegetation cover, calculated for each sandfly collection site. The NDVI was calculated from the multispectral bands of IKONOS-2 image.

After following atmospheric correction of the image, NDVI was used to characterize biophysical parameters of vegetation such as biomass and density of vegetation. The value of this index is normalized to the range of -1 to +1 . The NDVI is calculated by the following equation: NDVI $=(N I R-R) /(N I R+R)$, where NIR is the reflectance of vegetation in the near infrared band and $R$ is the reflectance of vegetation in the red band (Ponzoni \& Shimabukuro 2007).

The information in the NDVI values for each collection station were partitioned to obtain the landscape variables at different scales, as the complexity of the habitat (mean NDVI) and habitat heterogeneity [standard deviation (SD) of NDVI - NDVI SD] (Corrêa et al. 2011).

The percentage of vegetation cover was estimated with the help of a spherical densitometer. It is a convex mirror containing a grid with 36 vertices where the vertices are numbered reflecting the coverage of woody vegetation from four different perspectives (north, south, east and 

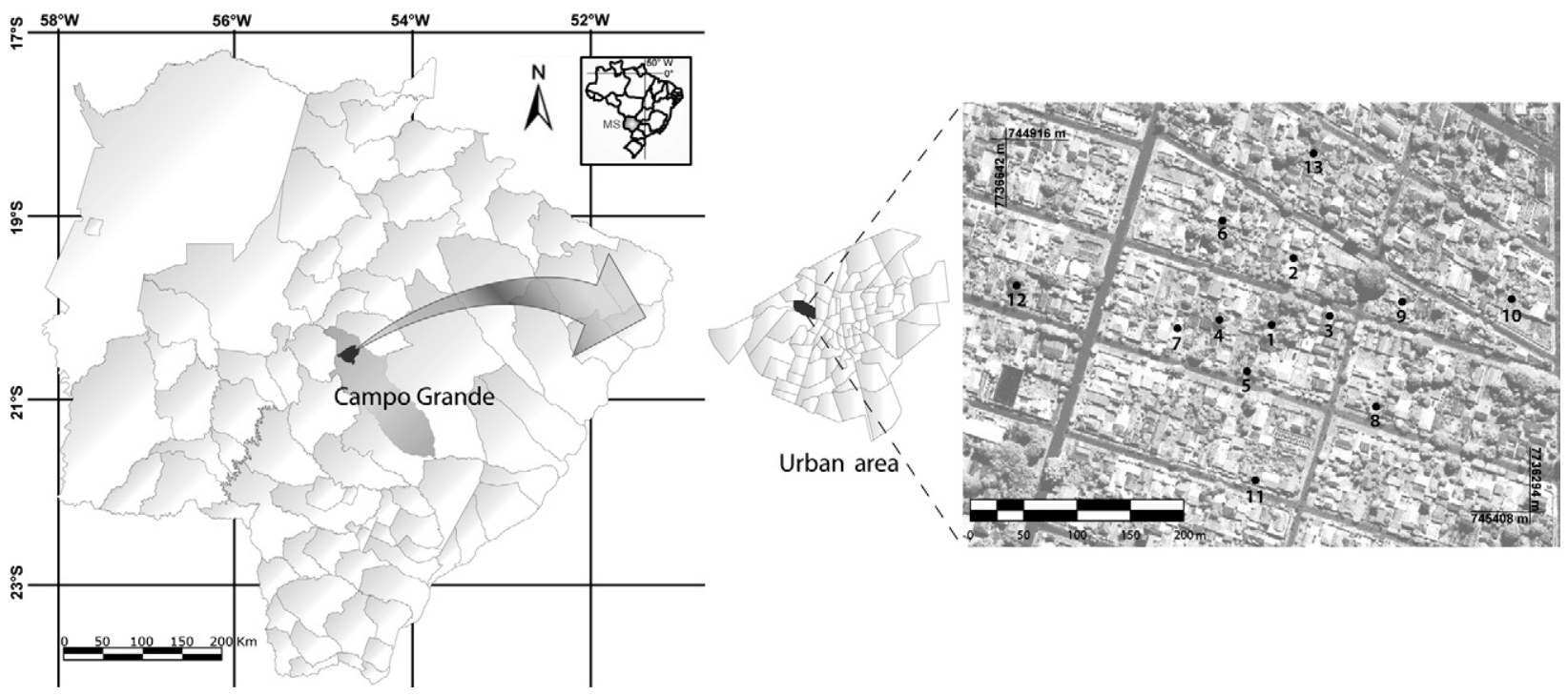

Fig. 1: localization of area of study, Campo Grande, state of Mato Grosso do Sul, and spatial distribution of capture points.

west), each observation with a rotation of $90^{\circ}$ relative to the previous each point. It was calculated the arithmetic mean of the four perspectives and then the percentage of vegetation was obtained by making up a rule of three. In each peridomicile five measurements were made in random distributions in the area surrounding the spot, with the exception of point 1 , where 10 measurements were made due to the greater extent of the peridomicile.

Statistical analysis - The simple linear correlation analysis (Spearman correlation coefficient) was used to estimate the association between the populations of males, females and total males and females with environmental variables: habitat complexity, heterogeneity and percentage of vegetation cover.

\section{RESULTS}

One thousand three hundred sixty-seven specimens were collected during the study period, which whose $74.1 \%(1,013)$ were male and $25.9 \%$ (354) were females, thus the male/female ratio was 2.86 . Table I shows the number and percentage of the sandflies captured during the study. We observed an eventual difference between the number of sandflies captured in houses with and without chickens. Except the point 11, in the other peridomestic areas there were domestic animals, such as chickens (point 1), cats (point 13) and dogs (other points).

Although this is a totally urbanized region, it was observed the presence of many fruit trees, especially mango (Mangifera indica). The analysis of linear correlation between the percentage of vegetation cover obtained by spherical densitometer and the density of sandflies found a significant correlation with the total number of specimens captured, as well as for males and females. For the analysis between the complexity of the habitat and sandflies, the same correlations were observed (Table II). However, there was no significant association between heterogeneity and the population of these flies.
TABLE I

Number and percentage of Lutzomyia longipalpis captured by residence, Campo Grande, Mato Grosso do Sul, 2009-2010

\begin{tabular}{lccc}
\hline Residence & Male & Female & $\begin{array}{c}\text { Total } \\
\mathrm{n}(\%)\end{array}$ \\
\hline 1 & 716 & 192 & $908(66.42)$ \\
2 & 14 & 5 & $19(1.39)$ \\
3 & 23 & 8 & $31(2.27)$ \\
4 & 28 & 19 & $47(3.44)$ \\
5 & 13 & 5 & $18(1.32)$ \\
6 & 25 & 19 & $44(3.22)$ \\
7 & 14 & 9 & $23(1.68)$ \\
8 & 8 & 4 & $12(0.88)$ \\
9 & 5 & 4 & $9(0.66)$ \\
10 & 18 & 4 & $22(1.61)$ \\
11 & 9 & 8 & $17(1.24)$ \\
12 & 72 & 46 & $118(8.63)$ \\
13 & 68 & 31 & $99(7.24)$ \\
\hline Total & 1,013 & 354 & $1,367(100)$ \\
\hline
\end{tabular}

TABLE II

Linear correlation coefficients between the environmental variables and abundance of Lutzomyia longipalpis

\begin{tabular}{lccc}
\hline Variables & Male & Female & Total \\
\hline NDVI & & & \\
Habitat complexity & $0.24^{a}$ & $0.18^{a}$ & $0.24^{a}$ \\
Habitat heterogeneity & -0.06 & 0.09 & -0.01 \\
Vegetation cover & $0.25^{a}$ & $0.27^{a}$ & $0.26^{a}$ \\
\hline
\end{tabular}

$a: \mathrm{p}<0.01$; NDVI: normalized difference vegetation index. 


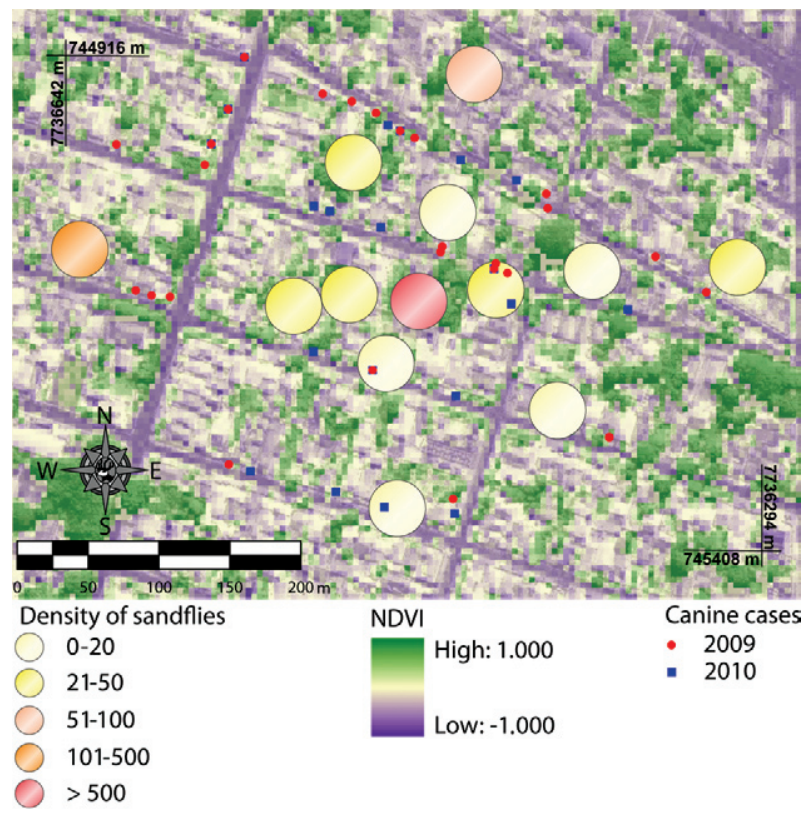

Fig. 2: distribution of canine cases reported and the abundance of sandflies in the study area, Campo Grande, state of Mato Grosso do Sul, 2009-2010.

Between January 2009-December 2010 there were no reported cases of human VL in the study area. Nevertheless, for the same period, there was notification of 45 cases of canine VL that have been georreferenced (24 notifications in 2009 and 21 in 2010). In Fig. 2, the relationship between the NDVI, the spatial distribution of reports of canine VL and abundance of sandflies can be observed.

\section{DISCUSSION}

In this study the predominance of males over females was observed in all months of collection. This finding is in accordance with those described by Quinnel and Dye (1994) who studied the abundance of Lu. longipalpis in Amazon. A similar result was described by Oliveira et al. $(2003,2006)$ with ratios greater than 2:1 for males to females of this species in the same city of Campo Grande. However, Galati et al. (2010) observed a higher proportion of females over males in the 2,449 specimens captured of 21 different species. Only the species Nyssomyia neivai were captured in similar proportion between the sexes (Galati et al. 2010).

The attractiveness of chickens to sandflies is often described in the literature (Lainson \& Rangel 2005). When working with eight different species of these flies, Teodoro et al. (2007) captured twice as many individuals in the presence of chickens. According to Ximenes et al. (1999), the presence of domestic animals associated with poor cleaning conditions contributes to the maintenance of high abundance of Lu. longipalpis.

Using data derived from satellite images, as the NDVI, allows the identification and monitoring of the diversity of vegetation, as well as the delimitation of geographical area and the areas of risk for some endemic diseases such as VL (Werneck \& Maguire 2002).
In this paper, some studied attributes of landscape positively affected the density and distribution of $L u$. longipalpis. The complexity of habitat was significantly associated with the density of Lu. longipalpis. While for the heterogeneity of habitat no significant association was observed. This result shows that large trees may offer a better micro environment where sandflies can find appropriate refuge and breeding place. As there is no reports about this subject with sandflies we have some difficult to discuss this aspect in our analysis. However, these data corroborate with the work of Corrêa et al. (2011), who reported that the abundance of chrysomelids (Insecta: Coleoptera) increased with habitat complexity but not with the habitat heterogeneity.

The highest abundance of $\mathrm{Lu}$. longipalpis was found in a residence during all months of collection. This result may be explained by the presence of a chicken coop and the high values of NDVI and vegetation present in this location. In Argentina, the spatial distribution pattern of Lu. longipalpis associated positively also with the presence of trees and shrubs, at least $50 \mathrm{~m}$ distant points of capture (Fernández et al. 2010). Carneiro et al. (2004) tested the average NDVI as an indicator of risk for VL in the state of Bahia, but the local record with $\mathrm{Lu}$. longipalpis and reported cases of the disease showed low values of NDVI, which may be suggestive of possible human activities on vegetation. Zeilhofer et al. (2008) correlated the NDVI values from different municipalities of MS with the occurrence of Lutzomyia whitmani and found no significant statistical difference from this analysis. Therefore, the associations found in this study suggest that populations of sandflies are concentrated in small areas where food supply is satisfactory, coinciding with the presence of large vegetation covering.

There are no reports in the literature to quantify the percentage of vegetation cover through the spherical densitometer and correlation with the density of sandflies, so this is the first report with this approach. Besides indirectly measuring the coverage, this device also enables measurement of the brightness of woody species. This fact is important since it is known that this feature can influence, positively or negatively, the development and establishment of vegetal covering and its variation can provide great diversity of micro-habitats within a biotope (Alvarenga et al. 2003, Lima Júnior et al. 2006, Suganuma et al. 2008).

The woody species are important for the density of sandflies, especially around and in cavities in tree trunks as reported by Deane (1956). Our data show that there is a positive relationship between these vectors and the presence of vegetation. This fact can be explained by the formation of a microclimate with conditions conducive to the continued existence and development of these specimens (Deane 1956, Forattini 1973). Another hypothesis is the attraction of sandflies to fruit trees in search of sugar for food (Müller \& Schlein 2004, Junnila et al. 2011).

In this study, the distribution of canine of cases VL from 2010 concentrated near areas with medium and high densities of Lu. longipalpis. Saraiva et al. (2011) reported the concentration of incident cases of canine VL 
in areas with small populations of vectors. Margonari et al. (2006) observed the occurrence of human and canine VL in areas with dense vegetation and the presence of sandflies. Corroborating Saraiva et al. (2011), in the present study, dogs were the animals most seen in the vicinity of the collection points. This finding is relevant from the epidemiological point of view as domestic dogs, apart from food source for sandflies, are considered the most important reservoirs of Leishmania in the urban areas (Marzochi \& Marzochi 1994).

The environmental changes resulting from human activities associated with migration and urbanization may explain, in part, why VL, a disease originally restricted to rural areas, began to occur endemically and epidemically at various urban centres in the country (Costa et al. 1990, 2007). Another point that deserves mention is the easy adaptation to peridomestic conditions presented by the vector $L u$. longipalpis, with the use of the accumulation of organic matter generated and the presence of domestic animals as a source of shelter and food, respectively (Aguiar et al. 1996).

A better understanding of the interaction between the urban environment, sandflies and their potential hosts, like humans and dogs, is needed to improve control strategies for VL. In this sense, the use of geotechnologies allows the identification of environmental features, present in anthropic areas endemic for VL and a large number of sandflies and thus suggests that in other areas with similar environmental characteristics may be the risk of human and pet infection by Leishmania.

\section{ACKNOWLEDGEMENTS}

To CCZ of the Municipal Health Secretariat of Campo Grande, for providing the necessary logistic support and helping us in field activities, to the residents of the houses who received our visits with patience, friendship and permitting us to make the captures on their residences, to Aline Casaril, for helping us with some of the experiments, and to Daniel Bray, for his correction of the English text.

\section{REFERENCES}

Aguiar GM, Medeiros WM, Marco TS, Santos SC, Gambardella S 1996. Ecologia dos flebotomíneos da Serra do Mar, Itaguaí, estado do Rio de Janeiro, Brasil. I - A fauna flebotomínica e prevalência pelo local e tipo de captura (Diptera: Psychodidae: Phlebotominae). Cad Saude Publica 12: 195-206.

Alvarenga AA, Castro EM, Lima Júnior EC, Magalhães MM 2003. Effects of different light levels on the initial growth and photosynthesis of Croton urucurana Baill in southeastern Brazil. Rev Arvore 27: 53-57.

Antonialli SAC, Torres TG, Paranhos Filho AC, Tolezano JE 2007. Spatial analysis of American visceral leishmaniasis in Mato Grosso do Sul state, Central Brazil. J Infect 54: 509-514.

Aparicio C 2001. Utilização de geoprocessamento e sensoriamento remoto orbital para análise espacial de paisagem com incidência de leishmaniose tegumentar americana, MsD Thesis, Instituto de Biociências/USP, São Paulo, 92 pp.

Barcellos C, Bastos FI 1996. Geoprocessamento, ambiente e saúde: uma união possível? Cad Saude Publica 12: 389-397.

Beck LR, Lobitz BM, Wood BL 2000. Remote sensing and human health new sensors and new opportunities. Emerg Infect Dis 6: 217-227.
Carneiro D, Bavia, ME, Rocha W, Lobão J, Madureira Filho C, Oliveira JB, Silva CE, Barbosa MG, Rios R 2004. Identificação de áreas de risco para a leishmaniose visceral americana através de estudos epidemiológicos e sensoriamento remoto orbital em Feira de Santana, Bahia, Brasil (2000-2002). Rev Baiana Saude Publica 28: 19-32.

Chust G, Pretus JL, Ducrot D, Ventura D 2004. Scale dependency of insect assemblages in response to landscape pattern. Landsc Ecol 19: 41-57.

Corrêa CC, Pimenta M, Dutra SL, Marco Júnior P 2011. Utilização do NDVI na avaliação da resposta de besouros herbivoros à complexidade e heterogeneidade ambiental em diferentes escalas no Bioma cerrado. In: Anais XV Simpósio Brasileiro de Sensoriamento Remoto, INPE, Curitiba, p. 3103-3110.

Costa CHN, Pereira HF, Araújo MV 1990. Epidemia de leishmaniose visceral no estado do Piauí, Brasil, 1980-1986. Rev Saude Publica 24: 361-372.

Costa CHN, Tapety CMM, Werneck GL 2007. Controle da leishmaniose visceral em meio urbano: estudo de intervenção randomizado fatorial. Rev Soc Bras Med Trop 40: 415-419.

Dajoz R 2005. Principios de ecologia, 7th ed., Artmed, Porto Alegre, $519 \mathrm{pp}$.

Deane LM 1956. Leishmaniose visceral no Brasil: estudos sobre reservatórios e transmissores realizados no estado do Ceará, Serviço Nacional de Educação Sanitária, Rio de Janeiro, 162 pp.

Fernández MS, Salomón OD, Cavia R, Perez AA, Acardi SA, Guccione JD 2010. Lutzomyia longipalpis spatial distribution and association with environmental variables in an urban focus of visceral leishmaniasis, Misiones, Argentina. Acta Tropica 114: 81-87.

Forattini OP 1973. Entomologia médica. Psychodidae, Phlebotominae, leishmaniose, bartonelose, Vol. IV, Edgard Blucher, São Paulo, 658 pp.

Galati EAB, Marassá AM, Gonçalves-Andrade RM, Consales CA, Bueno EFM 2010. Phlebotomines (Diptera: Psychodidae) in the speleological province of the Ribeira Valley: 2. Parque Estadual do Alto Ribeira (PETAR), São Paulo state, Brazil. Rev Bras Entomol 54: 477-487.

Galati EAB, Nunes VL, Boggiani PC, Dorval MEC, Cristaldo G, Rocha HC, Oshiro ET, Damasceno-Júnior GA 2006. Phlebotomines (Diptera: Psychodidae) in forested areas of the Serra da Bodoquena, state of Mato Grosso do Sul, Brazil. Mem Inst Oswaldo Cruz 101: 175-193.

Galati EAB, Nunes VL, Cristaldo G, Rocha HC 2003. Aspectos do comportamento da fauna flebotomínea (Diptera: Psychodidae) em foco de leishmaniose visceral e tegumentar na Serra da Bodoquena e área adjacente, estado de Mato Grosso do Sul, Brasil. Rev Patol Trop 32: 235-261.

Hirao T, Murakami M, Iwamoto J, Takafumi H, Oguma H 2008. Scale-dependent effects of windthrow disturbance on forest arthropod communities. Ecol Res 23: 189-196.

IBGE - Instituto Brasileiro de Geografia e Estatística 2010. [database on the Internet]. Censo demográfico 2010: Mato Grosso do Sul [cited 2011 July 1]. Available from: censo2010.ibge.gov.br/sinopse.

Junnila A, Müller GC, Schlein Y 2011. Attraction of Phlebotomus papatasi to common fruit in the field. J Vector Ecol 36 (Suppl.): S206-S211.

Lainson R, Rangel EF 2005. Lutzomyia longipalpis and the eco-epidemiology of American visceral leishmaniasis, with particular reference to Brazil - A Review. Mem Inst Oswaldo Cruz 100: 811-827.

Lima Júnior EC, Alvarenga AA, Castro EM, Vieira CV, Barbosa JPRAD 2006. Aspectos fisioanatômicos de plantas jovens de $\mathrm{Cu}$ - 
pania vernalis Camb. submetidas a diferentes níveis de sombreamento. Rev Arvore 30: 33-41.

Margonari C, Freitas CR, Ribeiro RC, Moura ACM, Timbó M, Gripp AH, Pessanha JE, Dias ES 2006. Epidemiology of visceral leishmaniasis through spatial analysis in Belo Horizonte municipality, state of Minas Gerais, Brazil. Mem Inst Oswaldo Cruz 101: 31-38.

Marzochi MCA, Marzochi KB 1994. Tegumentary and visceral leishmaniasis in Brazil: emerging anthropozoonosis and possibilities for their control. Cad Saude Publica 10: 359-375.

Müller GC, Schlein Y 2004. Nectar and honeydew feeding of Phlebotomus papatasi in a focus of Leishmania major in Neot Hakikar oasis. J Vector Ecol 29: 154-158.

Oliveira AG, Andrade Filho JD, Falcão AL, Brazil RP 2003. Estudo de flebotomíneos (Diptera: Psychodidae: Phlebotominae) na zona urbana da cidade de Campo Grande, Mato Grosso do Sul, Brasil, 1999-2000. Cad Saude Publica 19: 933-944.

Oliveira AG, Falcão AL, Brazil RP 2000. Primeiro encontro de Lutzomyia longipalpis (Lutz \& Neiva, 1912) na área urbana de Campo Grande, MS, Brasil. Rev Saude Publica 34: 654-655.

Oliveira AG, Galati EAB, Oliveira O, Oliveira GR, Espindola IAC, Dorval MEC, Brazil RP 2006. Abundance of Lutzomyia longipalpis (Diptera: Psychodidae: Phlebotominae) and urban transmission of visceral leishmaniasis in Campo Grande, state of Mato Grosso do Sul, Brazil. Mem Inst Oswaldo Cruz 101: 869-874.

Özbel Y, Balcioğlu C, Ölgen MK, Şimsek FM, Töz SÖ, Ertabaklar H, Demir S, Alkan MZ 2011. Spatial distribution of phlebotomine sand flies in the Aydin Mountains and surroundings: the main focus of cutaneous leishmaniasis in western Turkey. $J$ Vector Ecol 36 (Suppl.): S99-S105.

PMCG/PLANURB - Prefeitura Municipal de Campo Grande/Instituto Municipal de Planejamento Urbano 2010. Perfil socioeconômico de Campo Grande, 17th ed., PMCG, Campo Grande, 240 pp.

Ponzoni FJ, Shimabukuro YE 2007. Sensoriamento remoto no estudo da vegetação, Parêntese, São José dos Campos, 144 pp.

Quinnel RJ, Dye C 1994. Correlates of the peridomestic abundance of Lutzomyia longipalpis (Diptera: Psychodidae) in Amazonian, Brazil. Med Vet Entomol 8: 219-224.

Rohli RV, Veja AJ 2008. Climatology, Jones and Bartlett Publishers, Boston, 466 pp.

Root RB 1973. Organization of a plant-arthropod association in simple and diverse habitats: the fauna of collards (Brassica oleracea). Ecol Monograph 43: 95-124.
Rosa R 2003. Introdução ao sensoriamento remoto, 5th ed., Editora UFU, Uberlândia, 228 pp.

Saraiva L, Andrade Filho JD, Falcão AL, Carvalho DAA, Souza CM, Freitas CR, Lopes CRG, Moreno EC, Melo MN 2011. Phlebotominae fauna (Diptera: Psychodidae) in an urban district of Belo Horizonte, Brazil, endemic for visceral leishmaniasis: characterization of favoured locations as determined by spatial analysis. Acta Tropica 117: 137-145.

Sarmiento G 1984. The ecology of Neotropical savannas, Harvard University Press, Cambridge, $256 \mathrm{pp}$

SES/MS - Secretaria de Saúde do Estado de Mato Grosso do Sul 2011. Relatório de notificações de leishmaniose visceral humana, Governo do Estado de Mato Grosso do Sul, Campo Grande, 19 pp.

Silva ES, Carvalho FG, Silva EA, Fiozi E, Oliveira AG, Brazil RP 2000. Primeiro relato de leishmaniose visceral canina em área urbana do município de Campo Grande, Mato Grosso do Sul, In XXXVI Congresso Brasileiro de Medicina Tropical, Sociedade Brasileira de Medicina Tropical, São Luís, p. 318.

Stumpf KA 1993. The estimation of forest vegetation cover descriptions using a vertical densitometer, Inventory and Biometrics Working Groups session at the SAF National Convention, Society of American Foresters, Indianapolis, p. 163.

Suganuma MS, Torezan JMD, Cavalheiro AL, Vanzela ALL, Benato $\mathrm{T}$ 2008. Comparando metodologias para avaliar a cobertura do dossel e a luminosidade no sub-bosque de um reflorestamento e uma floresta madura. Rer Arvore 32: 377-385.

Teodoro U, Lonardoni MVC, Silveira TGV, Dias AC, Abbas M, Alberton D, Santos DR 2007. Luz e galinhas como fatores de atração de Nyssomyia whitmani em ambiente rural, Paraná, Brasil. Rev Saude Publica 41: 383-388.

Werneck GL, Maguire JH 2002. Spatial modelling using mixed models an ecologic study of visceral leishmaniasis in Teresina, Piauí state, Brazil. Cad Saude Publica 18: 633-637.

Ximenes MFFM, Souza MF, Castellon EG 1999. Density of sand flies (Diptera: Psychodidae) in domestic and wild animal shelters in an area of visceral leishmaniasis in the state of Rio Grande do Norte, Brazil. Mem Inst Oswaldo Cruz 94: 427-432.

Zeilhofer P, Kummer OP, Santos ES, Ribeiro ALM, Missawa NA 2008. Spatial modelling of Lutzomyia (Nyssomyia) whitmani s.1. (Antunes \& Coutinho, 1939) (Diptera: Psychodidae: Phlebotominae) habitat suitability in the state of Mato Grosso, Brazil. Mem Inst Oswaldo Cruz 103: 653-660. 